\title{
Dopaminergic enhancement of cognitive function
}

Citation for published version (APA):

Mehta, M. A., \& Riedel, W. J. (2006). Dopaminergic enhancement of cognitive function. Current Pharmaceutical Design, 12, 2487-2500. https://doi.org/10.2174/138161206777698891

Document status and date:

Published: 01/01/2006

DOI:

10.2174/138161206777698891

Document Version:

Publisher's PDF, also known as Version of record

Document license:

Taverne

Please check the document version of this publication:

- A submitted manuscript is the version of the article upon submission and before peer-review. There can be important differences between the submitted version and the official published version of record.

People interested in the research are advised to contact the author for the final version of the publication, or visit the DOI to the publisher's website.

- The final author version and the galley proof are versions of the publication after peer review.

- The final published version features the final layout of the paper including the volume, issue and page numbers.

Link to publication

\footnotetext{
General rights rights.

- You may freely distribute the URL identifying the publication in the public portal. please follow below link for the End User Agreement:

www.umlib.nl/taverne-license

Take down policy

If you believe that this document breaches copyright please contact us at:

repository@maastrichtuniversity.nl

providing details and we will investigate your claim.
}

Copyright and moral rights for the publications made accessible in the public portal are retained by the authors and/or other copyright owners and it is a condition of accessing publications that users recognise and abide by the legal requirements associated with these

- Users may download and print one copy of any publication from the public portal for the purpose of private study or research.

- You may not further distribute the material or use it for any profit-making activity or commercial gain

If the publication is distributed under the terms of Article $25 \mathrm{fa}$ of the Dutch Copyright Act, indicated by the "Taverne" license above, 
See discussions, stats, and author profiles for this publication at: https://www.researchgate.net/publication/6943886

\section{Dopaminergic Enhancement of Cognitive Function}

Article in Current Pharmaceutical Design · February 2006

DOI: 10.2174/138161206777698891 · Source: PubMed

CITATIONS

82

2 authors:

Mitul A Mehta

King's College London

293 PUBLICATIONS 10,727 CITATIONS

SEE PROFILE

Some of the authors of this publication are also working on these related projects:

Create new project "beliefs and values inventory" View project

English and Romanian Adoptees Brain Imaging Study View project
READS

280

Wim J Riedel

Maastricht University

149 PUBLICATIONS 7,250 CITATIONS

SEE PROFILE 


\title{
Dopaminergic Enhancement of Cognitive Function
}

\author{
Mitul A. Mehta ${ }^{\mathrm{a}, \mathrm{b}, *}$ and Wim J. Riedel ${ }^{\mathrm{c}, \mathrm{d}, \mathrm{e}}$
}

${ }^{a}$ Centre for Neuroimaging Sciences, Institute of Psychiatry, King's College, London, UK, ${ }^{b}$ PET Psychiatry Group,
MRC Clinical Sciences Centre, Hammersmith Hospital, Imperial College, London, UK, ${ }^{c}$ GlaxoSmithKline, Clinical
Pharmacology \& Discovery Medicine, Cambridge UK, ${ }^{d}$ Dept. of Neurocognition, Faculty of Psychology, University of
Maastricht, NL and ${ }^{e}$ Department of Psychiatry, University of Cambridge, UK

\begin{abstract}
The ascending dopamine system of the mammalian brain has been associated with motor, mnemonic and goaldirected or reward-related behaviour. The most progress in understanding the cortical mechanisms of dopaminergic modulation of function has been made with regards to short-term mnemonic (or working memory) function. Research in experimental animals strongly suggests that stimulation of dopamine D1 receptors in the prefrontal cortex can ameliorate spatial working memory related cognitive deficits, and may even enhance cognitive function in healthy animals. Research in humans has not been able to clearly replicate these findings, partly due to the lack of available agents that can safely be used. Low doses of dopamine D2 receptor agonists such as bromocriptine and pergolide may be able to enhance working memory and executive functions, but these effects may be dependent on the nature of the tasks used and the baseline performance levels of the subjects. Thus, the effects of dopaminergic cognitive enhancers may not be simple, or uniform across subjects. Systematic studies in humans carefully controlling task parameters are needed in order to specify the potential cognitive processes open to enhancement with dopaminergics. However, since the DA receptor subtypes in different brain regions appear to differentially influence similar functions, carefully defining the cognitive processes to be tested against potential therapeutics is an equally important goal. Studies in patients groups using selective dopaminergics are rather restricted, but show promise for designing large-scale clinical trials into the cognitive enhancing properties of potential therapeutic agents that act through the dopamine system.
\end{abstract}

\section{INTRODUCTION}

The ascending dopamine (DA) system of the mammalian brain has been associated with numerous functions. These include the regulation of motor output, reward-related behaviour, short-term memory and executive functions. While there has been considerable success in utilising the DA precursor levodopa ${ }^{1}$, and DA agonists such as pergolide and bromocriptine in the treatment of motor dysfunction associated with Parkinson's disease, it is the prospect of cognitive enhancement that has driven much research into systemslevel analyses of dopaminergic modulation in more recent years. The backbone of these efforts is formed by a considerable number of elegant studies carried out in experimental animals $[4,5]$. Advances in human studies have been hampered by a lack of agents available to replicate the discrete manipulations performed in experimental animals, although some findings to date have suggested that the advent of such drugs could bring therapeutic benefits to a wide range of patients, including those with brain injury following trauma or stroke, schizophrenia, Parkinson's disease and attentiondeficit hyperactivity disorder. *Address correspondence to this author at the Centre for Neuroimaging
Sciences (PO89), Institute of Psychiatry, London SE5 8AF, UK; Fax: +44 (0) 207919 2116; E-mail: m.mehta@iop.kcl.ac.uk

\footnotetext{
${ }^{1}$ Levodopa can also lead to increases in noradrenaline via neurons containing betahydroxylase, which converts DA to noradrenaline. However, changes in brain noradrenaline levels are considerably less than for DA, with some studies showing no changes [1-3]
}

The purpose of the present article is to review the available evidence in human volunteers regarding the potential efficacy and prospects for dopaminergic enhancement of cognitive functions and the prospective application to various neurocognitive disorders. Studies in experimental animals have highlighted the particular importance of dopaminergic neurotransmission for accurate performance of tasks mediated by frontal lobe and basal ganglia regions, and consequently such tasks have also been the focus of research in humans. Therefore this review will be centred on cognitive functions mediated by these brain regions. Indeed, deficits in tasks sensitive to damage to the prefrontal cortex (PFC) and connected regions of the basal ganglia are impaired in all psychiatric disorders as well as in many patients with traumatic brain injury, Parkinsonian disorders and progressive cortical degeneration disorders. In order to provide context for the studies in humans an overview of key research in experimental animals will also be provided following an overview of basic dopamine anatomy.

\section{DOPAMINERGIC PROJECTIONS AND DOPAMINE RECEPTORS}

The ascending DA projections comprise 2 major systems supported by anatomical descriptions and recent molecular descriptions of global-gene expression diversity [6]. The nigrostriatal system projects predominantly from the substantia nigra pars compata to the dorsal putamen and caudate nucleus (dorsal striatum) and globus pallidus. The ventral tegmental area (VTA) projects mainly to regions of the limbic system (e.g. nucleus accumbens, amygdala, anterior cingulate cortex) and widespread regions of the neocortex with 
higher density of projections to more anterior regions (mesocorticolimbic system) [7, 8]. Projections to posterior cortical regions and cerebellum are of considerably lower density. Receptor distributions show a similar pattern to the distribution of projection neurons, with the highest density of DA receptors in midbrain and striatal regions. Relatively high densities of receptors are also present in certain 'limbic' structures, including the amygdala and anterior cingulate cortex [9-11]. Cortical DA receptor densities are much lower with anterior brain regions having higher densities than more posterior cortical regions and the cerebellum. Indeed for these latter regions DA receptor densities are considered negligible in human and animal neuroimaging studies in vivo and are often used as 'reference' regions for defining receptor binding in other regions [12].

The structure and cellular functions of DA receptors have been reviewed extensively elsewhere [(e.g. ref. 13)] and therefore will only briefly be reviewed here. The physiological actions of DA are mediated by at least 5 distinct Gprotein coupled receptor subtypes, termed $D_{1}-D_{5}$ [14]. In 1978 two distinct subpopulations of DA receptors were first described, with one stimulating adenylate cyclase, and the other independent of this [15]. Kebabian and Calne [16] were the first to describe these subtypes as $D_{1}$ and $D_{2}$ receptors respectively. Subsequent studies have confirmed this distinction for both central and peripheral DA receptors ([see ref 17]). The $\mathrm{D}_{5}$ receptor shows considerable homology with the DA $\mathrm{D}_{1}$ receptor, so together they are referred to as D1, or $\mathrm{D}_{1}$-like receptors. The $\mathrm{D}_{3}$ and $\mathrm{D}_{4}$ receptors show considerable homology to $D_{2}$ receptors, so together they are referred to as $\mathrm{D} 2$, or $\mathrm{D}_{2}$-like receptors. Currently no compounds are licensed for use in humans that have significant selectivity for any one of the 5 receptor subtypes and therefore in this review we shall refer to the D1 and D2 receptor families, with specific mention of the $D_{1}-D_{5}$ receptor subtypes only when appropriate.

DA is synthesized from tyrosine, which is derived from the essential amino acid phenylalanine, or provided from the diet. As illustrated in Fig. 1, tyrosine is catalyzed to DOPA by tyrosine hydroxylase in the rate-limiting step in the biosynthesis of the catecholamines DA and noradrenaline ${ }^{2}$. DOPA is converted to DA by the enzyme L-aromatic amino acid decarboxylase. Synaptic DA is rapidly taken-up into the presynaptic terminal by the DA transporter or broken down by enzymes such as catechol-o-methyltransferase or monoamine oxidase. Fig. 1 also highlights the main mechanisms available for modulating central DA transmission, from alterations of precursor supply and blockade of transporter reuptake, to blockade of metabolising enzymes and direct action at the receptor sites. Although the use of some of these methods in the study of cognitive enhancement is limited (e.g. COMT-inhibitors such as tolcapone [19]), others (e.g. the DA D2 receptor agonist bromocriptine) are more widely used in research. The focus of studies cited in this

\footnotetext{
${ }^{2}$ However, it has been suggested that the synthesis of DA is not solely dependent on the availability of brain tyrosine levels. In vitro studies have shown that in a tyrosinefree medium DA synthesis continues, suggesting other sources of tyrosine can support DA synthesis. Among these are mobilised bound tyrosine, a low-molecular-weight peptide, like a dipeptide, or tyrosine from non-dopaminergic neurons [18].
}

review is, therefore, necessarily inclined towards the latter methodology, even though markers 1-5 in Fig. 1 should all be considered as potential targets for modulation of DA neurotransmission for cognitive enhancement.

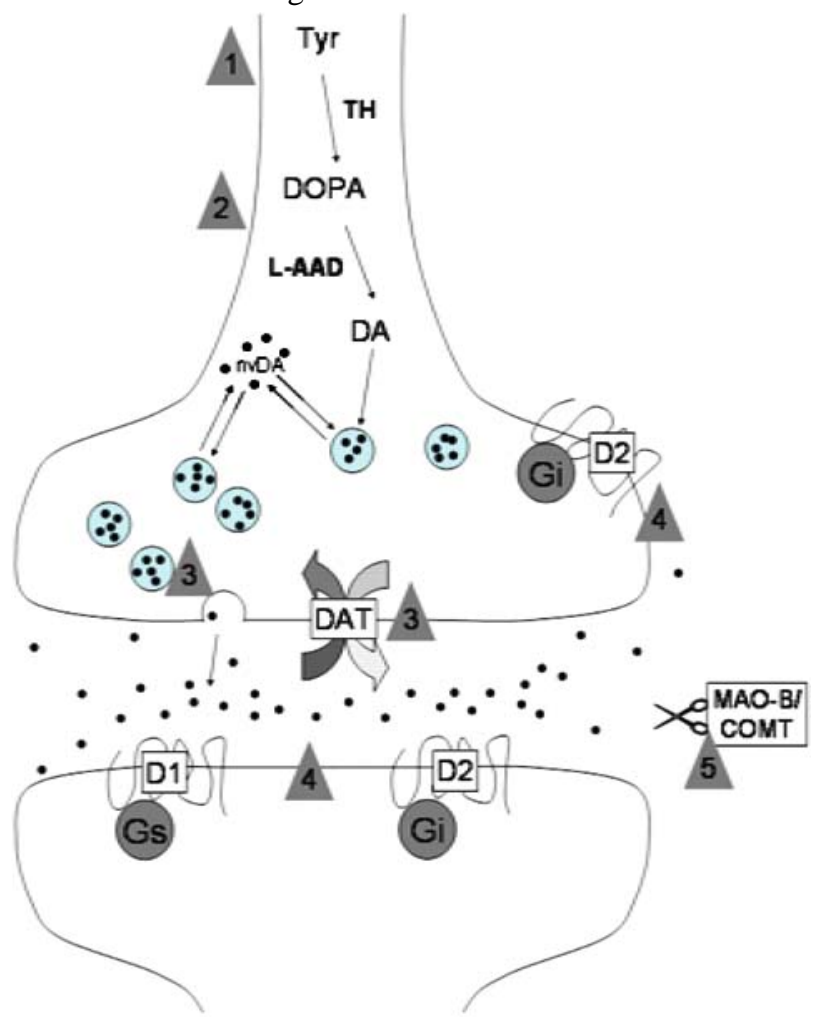

Fig. (1). Representational organisation of a dopamine (DA) synapse with a presynaptic dopaminergic projection neuron shown above and postsynaptic neuron (e.g. GABA neuron in the striatum) shown below. Tyrosine (Tyr) is converted to DOPA by the enzyme tyrosine hydroxylase $(\mathrm{TH})$, which is subsequently converted to DA (black dots) by L-aromatic amino acid decarboxylase (L-AAD). DA in vesicles exchanges with non-vesicular DA (nvDA). Extracellular DA is either rapidly taken up into the presynaptic terminal by the dopamine transporter (DAT) or metabolised by, for example, monoamine oxidase $\mathrm{B}$, or catechol- $O$-methyltransferase (COMT). Synthesis and release modulating autoreceptors (4) may be distinct receptor sites. Numbers indicate possible mechanisms by which dopamine neurotransmission may be modulated. Depletion or supplementation of the dopamine precursor, Tyr, results in reduced or increased synthesis and release of dopamine (1). Levo-dopa administration can increase dopamine synthesis and release (2). Blockade of the DAT with stimulant drugs such as amphetamine, methylphenidate, or cocaine, results in increased extracellular DA levels (3). Psychomotor stimulant drugs such as amphetamine and cocaine can also stimulate release of vesicular DA stores (3). Dopamine receptor agonists and antagonists can directly influence presynpatic and postsynaptic DA receptors (4). Alterations in metabolism (5) have been shown to result from different genetic polymorphisms or direct modulation of enzymatic function (e.g. tolcapone is a brain penetrant COMT inhibitor). DA receptors are members of the seven transmembrane domain G-protein coupled receptors. DA D1 receptors are coupled to $\mathrm{G}_{\mathrm{s}}$ and stimulate adenylate cyclase, whereas DA D2 receptors are coupled to $\mathrm{G}_{\mathrm{i}}$ and inhibit adenylate cyclase. Co-expression of DA receptor subtypes is observed in a number of brain regions. 


\section{EXPERIMENTAL ANIMALS}

Dopaminergic manipulations in experimental animals have demonstrated numerous functions associated with distinct brain regions that are dependent on intact DA transmission. For example, dopaminergic projections to the PFC and striatum are involved in spatial working memory functions, and striatal and amygdala DA are important for learning/conditioning. This review will focus on frontal and striatal regions as the most progress has been made for functions predominantly mediated by them in translating research in experimental animals to humans.

The delayed-response task was one of the first cognitive tests shown to be sensitive to damage to the PFC. Ablation, excitotoxic damage, or cooling of the region around the principal sulcus in the lateral PFC of the monkey impairs accuracy of memory-guided performance on this task of spatial working memory without impairing stimulus-guided motor responses [20-25]. In this task and its variants the animal is required to view a stimulus in a specific location before a short delay (typically a few seconds, although DA may also be important for memory over much longer delays [26]). After the delay period the animal is required to make a correct memory-guided spatial response in order to receive a reward. In a landmark study Brozoski and colleagues [27] showed that after 6-hydroxydopamine (6-OHDA) lesions of the PFC in 3 monkeys, performance on a version of the delayed-response task was impaired to a similar extent as surgical ablation of the same area (later replicated by Roberts and colleagues [28]). Despite the fact that the pharmacological lesions also depleted noradrenaline and serotonin, but to a lesser extent, the authors concluded that DA was the neurotransmitter responsible for the impairments based on 2 additional findings. First, other animals with more significant noradrenaline and serotonin depletion, but less DA depletion showed no evidence of impaired performance. Second, systemic administration of the DA precursor, levodopa or the non-selective DA agonist, apomorphine, reversed the impairment in the DA depleted animals. Although the delayed-response task as used by Brozoski and colleagues and others has been criticised because the animal can change its posture during the delay in accordance with the spatial location of the reward this appears to occur rarely. An oculomotor version of the delayed-response task (ODR) is free from this confound, and is also sensitive to dopaminergic manipulations within the PFC. Direct application of specific DA receptor agonists and antagonists can modulate accuracy of performance and associated neuronal activity during the delayed-response task. Direction selective neurons showing sustained activity during the delay period of delayedresponse tasks, or 'memory fields', are modulated by DA D1 selective compounds, but not DA D2 selective compounds [29-31]. By examining the effects of iontophoretic application of the DA D1 selective antagonist SCH31966, Williams and Goldman-Rakic [30] showed that concentrations just above threshold for effect dramatically enhanced the memory fields of prefrontal cortical cells; this effect was reversed by a DA D1 receptor agonist. However, with higher doses of the same DA D1 receptor antagonist the memory fields were markedly disrupted. The relationship between DA D1 receptor stimulation and activity of memory fields was formulated as non-linear by this study and subsequent behavioural investigations in both rodents and monkeys [30, 32-35]. Thus, the spatial tuning of prefrontal neurons engaged in spatial working memory is enhanced at moderate levels of D1 receptor stimulation and reduced at both lower and higher levels of stimulation. This specificity of action can be accounted for by the location of DA D1 receptors on the spines of pyramidal neurons, modulating excitatory output from the PFC, while controlling inhibitory neuronal modulation of the same output [36].

Impairments in spatial working memory induced by downregulation of DA D1 receptor function after chronic treatment with the non-selective DA antagonist haloperidol, or with ageing, can be reversed by systemic administration of the DA D1 receptor agonist prodrug ABT-431 [37, 38]. This drug is converted into a potent full agonist of the DA D1 receptor in the brain and early studies in Parkinson's disease suggest that it may be a useful agent to assess therapeutic enhancement of working memory in humans [39]. In younger monkeys with no DA depletion even a sensitizing regimen of low doses of ABT-431 failed to produce enhancements in spatial working memory clearly seen in older monkeys [37]. While the same may not be true in human volunteers, as studies using agonists with DA D1 receptor affinity can improve spatial working memory performance in younger subjects [40], these findings do accord with previous suggestions that healthy individuals may be performing close to their optimum level for working memory and therefore it may be easier to impair rather than enhance their performance [41, 42].

Older animals are also sensitive to the effects of DA D2 receptor agents in modulating spatial delayed-response performance. When given systemically, delayed-response performance is enhanced by moderate doses of the DA D2 receptor agonist quinpirole, but not lower doses (thought to act predominantly via presynaptic autoreceptors) [43]. In younger monkeys, without loss of DA D2 receptor function, lower doses of quinpirole impaired delayed-response performance, whereas moderate doses enhanced performance. Fine motor performance and "hallucinatory like" behaviours were also modulated by systemic administration of quinpirole. Taken together, the findings were interpreted as reflecting a greater loss of prefrontal rather than motor area DA function with age. However, since the study used systemic administration of quinpirole, action in the striatum to modulate delayed-response performance cannot be ruled out. Indeed 6-OHDA lesions of DA in the caudate nucleus can also significantly impair performance of marmoset monkeys on the delayed-response task [44].

In addition to accurate performance of the delayedresponse task, DA cell firing in the VTA is also thought to be important for acquisition or learning of the task $[45,46]$. These findings formed the basis of a more general theory developed by Schultz and colleagues [47, 48] that learning may be driven by errors in expectations of salient, or rewarding [49] events, with DA neurons signalling such errors. In a simple stimulus-reward association learning task DA neurons fire to unpredicted rewards or reward-predicting stimuli, but do not fire to predicted rewards, and are depressed by omitted rewards. DA may therefore act as an effective 'teaching' signal in learning cognitive tasks. The ini- 
tial short-latency firing of DA neurons to unexpected stimuli has also been proposed to represent an essential component in switching attention to behaviourally important, salient stimuli [50], including apparently non-rewarding stimuli such as tones or lights. More recent accounts have, however, proposed that aversive stimuli (which are both salient and non-rewarding) may actually inhibit DA neuron firing and subsequently activate DA neurons through an opponent process [49]. Resolution of these differing views may have implications for understanding the precise effects of DA agents in modulating various forms of learning.

In addition to attentional switching discussed above, other aspects of attentional function may also be modulated by, for example, administration of specific DA receptor agents to the medial PFC in the rat [51]. Performance of a continuous performance test requiring sustained and divided attention to spatial cues was unaffected by DA D2 receptor agents. The effects of DA D1 receptor drugs, was, however more complicated. Animals performing well at baseline, before drug administration $(>75 \%)$, were impaired in terms of performance accuracy by the DA D1 antagonist $\mathrm{SCH} 23390$. For animals with poorer baseline performance ( $<75 \%)$, medial PFC infusion of the D1 DA receptor agonist SKF 38393 improved accuracy. Although the precise neuronal mechanisms underlying these performance changes have not been elucidated to the same level as those described for spatial working memory, these results strongly suggest that, as with working memory functions, there is an optimal level of DA D1 receptor stimulation required for accurate attentional performance. Importantly, they indicate that the effects of DA agents as potential cognitive enhancers may not be simple or uniform across groups of subjects. Indeed, preliminary results from some studies in humans support this conclusion $[52,53]$.

In conclusion, the research in experimental animals has shown that under-, or over-stimulation of prefrontal DA D1 receptors is associated with poor spatial working memory accuracy and, possibly, attentional performance. Although DA D2 receptors agents do not influence the activity of 'memory fields' in the PFC they may have a preferential role in prefrontal neural activity associated with memory-guided responding in the delayed-response task [54]. Moreover, the effects of specific DA receptor agents on subcortical activity related to working memory performance is yet to be described, but may be important in understanding the effects of systemic administration of compounds [42]. Striatal DA function (including the nucleus accumbens) is, however, important in learning and certain attentional functions [44, 55-57]. The lack of availability of selective ligands has also limited research into the precise role of other DA receptor systems such as $\mathrm{DA}_{3}$ or $\mathrm{DAD}_{4}$.

\section{STUDIES IN HUMANS}

Lueck and colleagues [58] showed that patients with Parkinson's disease were impaired on an oculomotor version of the delayed-response task, demonstrating relevance of the studies in experimental animals to humans. However, since the patients were medicated with dopaminergics at the time of investigation it is difficult to determine the precise role of DA in the impairments seen. Indeed, despite impaired per- formance in patients when compared to controls [59], studies of the effects of dopaminergic medication on this task show no clear performance changes in patients $[60,61]$ (spatial working memory tasks that require additional strategic, or executive functions may, however, be sensitive to dopaminergic medication in Parkinson's disease [60, 62]). In healthy volunteers, bromocriptine, a DA D2 receptor agonist, was shown to improve delayed-response performance accuracy in 8 adults [63] using a dose of $2.5 \mathrm{mg}$. The task involved pointing to a spatial location presented on a computer screen 8 seconds earlier. Unfortunately, the improvement of $44 \%$ in spatial accuracy of recall was not replicated in a larger group of volunteers [64]. This same study did however show improved spatial recall accuracy with a lower dose of bromocriptine of $1.25 \mathrm{mg}$. It was suggested that a higher incidence of mild side effects (e.g. nausea) experienced by the group given $2.5 \mathrm{mg}$ bromocriptine may have 'masked' any improvement in performance, or that the differences in timing of task administration relative to drug ingestion may explain differences between studies. The non-selective DA antagonist haloperidol produced impaired performance on the spatial working memory task in the same study, while a non-spatial analogue was unaffected by either drug. This was taken as evidence that DA manipulations may be more effective in modulating spatial rather than non-spatial working memory, a notion supported by a more recent investigation using both bromocriptine $(2.5 \mathrm{mg})$ and pergolide $(0.1 \mathrm{mg})$ that was unable to show modulation of an object working memory task (the task battery did not include a spatial working memory task) [65]. Although the group that conducted the original investigation of bromocriptine and working memory also demonstrated improvement in spatial working memory after $1.25 \mathrm{mg}$ bromocriptine in a subsequent study [66], other groups were not able to demonstrate the same effects with $2.5 \mathrm{mg}$ bromocriptine [40, 52, 67]. A more complex task measuring spatial memory span was improved in one study using $1.25 \mathrm{mg}$ bromocriptine [68], although other spatial memory tests were unaffected.

The mixed findings of studies using bromocriptine with spatial working memory tests are summarised in Table $\mathbf{1}$ and collectively suggest that while performance may be improved, a lower dose of drug may be more effective. Since bromocriptine is a DA D2 receptor agonist, more reliable effects on spatial working memory performance may be seen after administering a drug that is more potent as an agonist at the DA D1 receptor as suggested by research in experimental animals. Pergolide (a mixed D1/D2 receptor agonist) at a dose of $0.1 \mathrm{mg}$ did improve spatial working memory performance in a group of 16 volunteers, but only at longer delays of 16 seconds, not 8 seconds [40]. (In the same study $2.5 \mathrm{mg}$ bromocriptine did not influence performance in a separate group of 16 volunteers.) The preferred conclusion of this study is that the additional effect of pergolide at DA D1 receptors is responsible for the improved performance seen. However, as has previously been noted [69], pergolide is significantly more potent an agonist of the DA D2 receptor than bromocriptine, and therefore it remains possible that the observed improvements in spatial memory were due to action at the DA D2 receptor. Although plasma prolactin levels were reduced by similar amounts by both drugs this hormonal marker of DA D2 receptor effects may not be sensitive to 
Table 1. Spatial Working Memory Tasks and the Effects of DA Agonists on Performance in Healthy Volunteers

\begin{tabular}{|c|c|c|}
\hline Drug reference & Agonist at D1/D2 receptor? & $\begin{array}{c}\text { Improved performance in spatial } \\
\text { delayed-response task (or similar) }\end{array}$ \\
\hline \hline Bromocriptine [63] & D2 & $\checkmark$ \\
\hline Bromocriptine [64] & D2 & $\checkmark$ \\
\hline Bromocriptine [66] & D2 & $\times$ \\
\hline Bromocriptine [52] & D2 & $\times$ \\
\hline Bromocriptine [40] & D2 & $\checkmark$ (spatial span test) \\
\hline Bromocriptine [68] & D2 & $\times$ \\
\hline Bromocriptine [67] & D2 & $\checkmark$ (spatial pattern recognition test) \\
\hline Pergolide [40] & D2/D1 & $\times{ }^{c}$ \\
\hline Pergolide [72] & D2/D1 & $\times$ \\
\hline Pergolide [67] & D2/D1 & $\times$ \\
\hline
\end{tabular}

${ }^{a}$ Improved performance only seen with lower dose. ${ }^{\mathrm{b}}$ A spatial recognition task, and self-ordered spatial search task were unaffected by bromocriptine. ${ }^{\mathrm{c}}$ A subgroup of volunteers with the higher baseline memory span scores had improved accuracy after drug on the delayed-response task. A spatial span task was unaffected, but was also improved in the higher baseline memory span group.

differences in receptor stimulation at 'low' doses [70, 71]. Unfortunately, two more recent study using $0.1 \mathrm{mg}$ pergolide were both unable to clearly demonstrate improved spatial working memory performance using spatial and object variants of the delayed-response task [67, 72].

When baseline reading span was factored in to the analysis of the pergolide study by Kimberg and D'Esposito [72], the clearest finding was a relative improvement in delayedresponse performance accuracy (spatial and object), but only in the group with a higher reading span. This result parallels earlier findings from the same group using $2.5 \mathrm{mg}$ bromocriptine for which performance on more executive function' tasks such as the Wisconsin Card Sorting Test was improved in high-span subjects, but worsened in low-span subjects [73]. However, both of these findings oppose the results of earlier studies [52, 53, 68], in which performance was improved in the low-span subjects. Kimberg and colleagues [52] did not observe main effects of bromocriptine on spatial delayed-response or executive function measures, but did observe interactions with baseline reading span for the executive function measures. Those with low reading spans (as determined by a median split) were improved and those with higher spans were worsened by bromocriptine. A number of differences exist between this and their later study [73] which showed the opposite effects, including subtle changes in task parameters, different numbers of participants, and a different delay between drug ingestion and neuropsychological assessment. The different delays are important because this could influence the magnitude and type of effect observed. For example, bromocriptine is thought to have biphasic effects, such that at low doses (or early in its pharmacokinetic timecourse, i.e. before $t_{\max }$ during absorption and distribution of the drug) it has predominantly presynaptic effects, whereas at higher doses (or later in its timecourse, i.e after $t_{\max }$ during elimination of the drug) it has predominantly postsynaptic effects $[74,75]$.
Differences in task parameters across the studies described may also be responsible for the differential effects seen. For example, the studies by Luciana and colleagues showed improved delayed-response performance in a task that required memory-guided responses to spatial locations (see Table 1). Müller and colleagues failed to show improved performance on a task that required the recognition, rather than recall, of the location of complex pattern stimuli [40]. As noted by Luciana and colleagues [64], with regards to their own findings, such task differences may be described in terms of requirement for preparation of a motor response, rather than in terms of mnemonic function. The importance of the mesostriatal DA system in motor (response) readiness has previously been highlighted in both animal and human studies [76, 77]. However, it is difficult to ascertain the importance of the neuropsychological task parameters in the interpretation of the human studies as no systematic investigations have been conducted to date. Such a study would require the use of a series of similar tasks in which either the stimulus properties, or the nature of the delay period, or the mode of response (e.g. recall versus recognition) were varied. A recent study in Parkinson's disease used a similar design to examine the influence of dopaminergic medication withdrawal on manipulation versus maintenance of verbal information (sequences of 4 letters) held in working memory [62]. The results were clear. DA medication withdrawal led to worse performance when manipulation (reordering of letters) was required compared with maintenance. Similar studies have yet to be conducted in healthy volunteers.

The age of participants may also be an important factor due to possible 'naturalistic' reductions in markers of the DA system with age [78], and the more positive responses to DA agonist treatment seen in older animals [37, 43]. Indeed, some studies showed that improvement was greater in human volunteers with lower baseline ability (although others showed the opposite) $[52,53,68,72,73]$. There are, how- 
ever, no clear examples of selective DA agonists being used with working memory and executive function tasks in elderly human volunteers. In one study [79], the DA precursor levodopa was shown to improve effortful memory, but not semantic memory in a group of elderly normal volunteers in a placebo controlled, double-blind study. Two other studies used the synthetic DA agonist piribedil. The first of these was conducted in a general practice setting with over 500 patients, most of whom showed improved memory, although the lack of a control group, or placebo arm makes interpretation of this study difficult [80]. The second study demonstrated improved acquisition of skill learning after 2 months of piribedil $50 \mathrm{mg}$ per day in 37 older volunteers, although the effect was limited to the group of volunteers aged 65-74, and was not present in those aged 75-82, suggesting variations in sensitivity to positive effects within older populations. In younger volunteers, a small placebo-controlled study by Schuck and colleagues [81] demonstrated improved immediate and delayed free recall after $3 \mathrm{mg}$ piribedil. A verbal working memory test based on the digit span test was also included in this study, but was not improved. Although piribedil acts directly on DA D2 and D3 receptors, as well as on D1 receptors via its main active metabolite, it is also an antagonist at $\alpha_{2}$-adrenoreceptors, suggesting that some of its apparent positive effects may be mediated, or even limited by its action on the adrenergic system. Thus, on the basis of these studies in humans and experimental animals, largescale investigations of the memory enhancing properties of selective DA agonists are urgently required, particularly in older volunteers.

Even when studies are able to demonstrate a positive influence of dopaminergic intervention on cognitive function, not all participants respond. As already suggested, individual differences in baseline performance may be an important factor here. However, these and other putative differences that are yet to be described, could be mediated in part by genetic variations. These could influence numerous processes from pharmacokinetics [82] and enzymatic catabolism [83], to the binding of the drug at specific receptor sites [84]. Considerable interest has surrounded the identification of a substitution polymorphism of the catechol-o-methyltransferase (COMT) gene at codon 158 (COMT Val ${ }^{158}$ Met polymorphism) [83]. Broadly, the prevailing hypothesis is that the high activity form of COMT (the Val allele) leads to reductions in cortical DA levels and associated impairments in networks mediating working memory and other executive functions [85], although the COMT $\mathrm{Val}^{158} \mathrm{Met}$ polymorphism could also affect other neurotransmitters - particularly noradrenaline - and other regions including the striatum [86], and the precise effects of such a polymorphism may also interact with disease processes [87]. Nonetheless, phenotypic variations due to such a genetic polymorphism could contribute to individual differences at baseline that predict drug response, or influence drug response directly [88].

In summary, the studies in healthy human volunteers to date have suggested that spatial working memory and other executive functions may be improved by administration of low doses of DA agonists. However, a number of prominent caveats are highlighted, including the nature of task design, the baseline ability and age of the subject, genetic polymor- phisms and the relative potency of drugs at DA D1 and D2 receptors. It should also be noted that the repertoire of compounds used in these studies is limited, with no published studies using potent and selective DA D1 agonists available at the time of writing. In addition, most studies have been conducted in younger volunteers, whereas research in experimental animals has suggested that it may be easier to improve function in older subjects with 'naturally' impaired DA systems.

\section{PSYCHOMOTOR STIMULANTS}

Stimulant drugs such as amphetamine, methamphetamine, cocaine and methylphenidate can influence DA neurotransmission by blocking reuptake at the transporter site, thereby increasing extracellular levels of DA, and stimulating release from the presynaptic terminal. However, these compounds also have significant, but varying effects at the noradrenaline and serotonin transporter sites [89]. Therefore, attribution of possible cognitive enhancing properties of this class of compounds specifically to DA neurotransmission is problematic. Even so, the psychomotor stimulants do have a significant influence on the dopamine system and their widespread use in the treatment of ADHD, as well as their established ability to improve attentional function, even in healthy volunteers [90-92] indicate that they should not be omitted from a discussion of dopaminergic influences on cognitive function. Using the Cambridge Neuropsychological Test Automated Battery (CANTAB; www.cantab.com), Elliott and colleagues [93] demonstrated improvements on a number of tests sensitive to frontal lobe and striatal damage using $20 \mathrm{mg}$ and 40mg methylphenidate. A test of spatial working memory requiring ordered searches through an array of boxes for hidden tokens was improved, as was a test of sustained attention. The study also assessed planning ability on two versions of the Tower of London Test. In one version that required planning, but no execution of the plans, performance accuracy of the difficult problems was improved, but only on the first test session of the cross-over design. In another version that required execution of the plans subjects were less accurate, but quicker to initiate solution performance, for the difficult problems, but only on the second session of the cross-over design. These complex findings suggest that the effects of methylphenidate can interact with the novelty of the tests to the subjects, since they received no training sessions prior to the study. That is, the increased arousal associated with novelty, combined with administration of methylphenidate may act to improve performance, but the absence of novelty on the second session may disrupt performance, possibly via subcortical effects on DA systems. This evidence for this latter effect was the increased response times and impaired performance accuracy on the planning task.

Other studies using dopaminergic and noradrenergic agents have provided some support for interpretations of drug effects that incorporate novelty $[94,95]$. However, in a follow-up study using the same spatial working memory test [53], 40mg methylphenidate was found to improve performance in 10 subjects that had received pre-study training. In a finding that paralleled earlier studies with bromocriptine [52], it was those with lower baseline memory spans that 
showed the greater performance improvements after drug. The same 10 volunteers were also scanned using positron emission tomography during performance of the working memory task. This showed that methylphenidate modulated the dorsolateral PFC and posterior parietal lobe, suggesting that disorders affecting functioning of these brain regions may benefit from methylphenidate.

Rogers and colleagues [96] also tested the effects of $40 \mathrm{mg}$ methylphenidate on fronto-striatally mediated cognitive function using a test of cognitive flexibility. A similar test had been used by Elliott and colleagues [93], but the drug did not influence performance. The test required the learning of stimulus-response associations to compound stimuli that could be segregated along two distinct dimensions. The key stage of the task required shifting attention from one dimension of stimuli to another, akin to a category shift in the Wisconsin Card Sorting Task [97]. The young healthy volunteers made very few errors and therefore we cannot be sure that a ceiling effect reduced the sensitivity of this task to possible effects of methylphenidate. By adding an extra dimension Rogers and colleagues [96] produced a version of the attention-set shifting task that was sensitive to methylphenidate, with the drug reducing errors during the key shifting stage, while responses were slowed. They concluded that increased catecholamine neurotransmission disrupted allocation of attention to relevant and irrelevant features of the environment. Children with ADHD given the attention-set shifting test in a similar study design showed remarkably similar effects on the same task, with methylphenidate reducing set shifting errors and thus, normalising performance [98].

In contrast to the findings in young healthy volunteers, and at odds with predictions from experimental animal studies described earlier, elderly male volunteers given a similar acute dose of methylphenidate (20mg or $40 \mathrm{mg}$ ), showed no improvement on tests of self-ordered spatial working memory, digit memory span, spatial memory span, planning, attention-set shifting, or motor inhibition [99]. The authors suggested that the doses of methylphenidate used may have disrupted functioning of the PFC and that lower doses may still be effective for improving cognition in elderly volunteers. Alternatively, they suggested that the between-subjects design might have reduced statistical power to detect changes in cognitive performance. This explanation is in keeping with findings of baseline dependent effects of drugs, including methylphenidate, on cognitive function. A large variation in performance in the different groups may mask a small, baseline dependent effect of the drug.

In summary, methylphenidate is able to produce pronounced effects of spatial working memory and sustained attention in young healthy volunteers. The more complex findings on tests of planning and attentional-set shifting highlight that improvements in some areas of cognition may be accompanied by impairments in other areas. These effects have not been replicated in elderly volunteers, a group predicted to show enhanced effects of dopaminergic agonists from research in experimental animals, although we are yet to see within-subjects placebo-controlled studies examining this question in humans.

\section{CLINICAL IMPLICATIONS}

Persistent cognitive deficits are common complaints in a number of disorders including schizophrenia, attention deficit disorder as well as after traumatic brain injury and cerebrovascular accidents (CVA). Cognitive deficits can be a major hindrance to normal social living and achievement in school or the workplace. Intervention strategies can potentially reduce significant disability and considerable healthcare costs. The frequency of working memory and attentional deficits in a wide range of patients and the known involvement of DA in working memory function described in this review indicates that DA therapeutics are an important strategy in the amelioration of deficits in such patients. Discussion of clinical implications is focussed on three indications in order to give an overview of issues and limitations within the literature. The reader is directed to other recent reviews for a more general coverage of this topic in relation to other disorders [100-103].

Schizophrenia is commonly associated with numerous cognitive deficits, most notably in the domains of working memory and episodic memory, as well as more general deficits in executive function as suggested by difficulties on tests of cognitive flexibility and sustained attention. GoldmanRakic and colleagues have reviewed the putative role of DA D1 receptor stimulation in targeting the working memory deficits in patients with schizophrenia $[36,104]$ in relation to pathological substrates and animal research. In vivo studies in patients with specific pharmacological challenges are, however, lacking. The precise nature of DA dysfunction in the PFC of patients with schizophrenia is also unclear. Three studies to date have used PET neuroimaging to measure the density of DA D1 receptors in the PFC of neuroleptic naïve patients with schizophrenia: one study showed reduced ligand binding [105], one showed no change [106], and a third study showed increased ligand binding [107]. The former and latter of these studies also demonstrated a significant correlation between cognitive task performance measures and dorsolateral PFC receptor densities. The main difference between the three studies is that the latter utilised a different radiolabelled ligand to the former two. The binding of the DA D1 receptor antagonist SCH23390 was decreased, or unchanged in patients with schizophrenia [105, 106], whereas the binding of another D1 antagonist NNC-112 was increased [107]. However, in vivo binding of these ligands is differentially affected by DA depletion, with SCH23390 showing a paradoxical decrease in binding and NNC-112 being unaffected [108]. Decreased endogenous DA within a competition model would predict increased numbers of available receptors for binding of the ligand. If the differences between the studies reflects the different ligands used, then the increased binding of NNC-112 may reflect an increase in DA D1 receptor expression secondary to a DA deficit in the cortex [109]. Together with the increased stimulation of subcortical DA D2 receptors previously hypothesised and reported [110], this is consistent with the notion of two co-existing levels of DA dysfunction in schizophrenia. Drugs that increase prefrontal cortical DA D1 receptor stimulation to target cognitive dysfunction may therefore prove to be a valuable adjunct to current neuroleptic drugs for targeting positive symptoms of the disorder such as hallucinations and paranoid and delusional thinking. 
Cognitive deficits associated with ADHD may also benefit from DA stimulation and improved performance is often achieved after psychomotor stimulant treatment [98, 111113]. The precise nature of cognitive deficits seen in ADHD and a complete review of the role of stimulant treatment in cognitive enhancement in ADHD is beyond the scope of this review, and has recently been discussed elsewhere in detail (e.g. [114-119]). In summary, ADHD appears to be associated with a wide range of deficits in areas of motor inhibition, sustained attention, episodic memory and motor timing, although there is current debate over the reliability of some of these deficits and specificity of some of these deficits to ADHD. While stimulant treatments, such as methylphenidate, can enhance performance on some of these domains, what is currently lacking is studies attempting to parse out these improvements to changes in dopaminergic or noradrenergic neurotransmission [42, 116]. Non-selective DA agonists have been used in small samples of children. Piribedil and amantadine (a non-competitive NMDA antagonist that also results in DA release) were not found to be clinically effective [116]. This may have been because the doses used were too high. Levodopa was effective in a number of small studies (but with some suggestion of less efficacy than methylphenidate) $[120,121]$. However, none of these studies examined the potential cognitive enhancing properties of dopaminergic agents in these hyperactive groups. Langer and colleagues [122] tested the effects of a 3week titration of levodopa (with carbidopa to minimise peripheral metabolism) up to doses of $600 \mathrm{mg}$ per day in a placebo-controlled design in 8 hyperactive boys. Teacher ratings of hyperactivity were reduced after levodopa. Sustained attention performance was also improved, with accuracy improving with faster stimulus presentation. A verbal paired associates learning task previously shown to be sensitive to an acute dose of amphetamine [123] was unaffected by levodopa. A more recent study used the non-selective DA agonist, pergolide, and showed improved performance in tests of memory and learning in a group of 7 children with restless leg syndrome and ADHD [124], but did not include a control, or placebo group to compare with the drug treatment group. Such methodological problems diminish the current utility of this and other studies. Moreover, diagnostic criteria have altered since most of these studies were initially conducted, with criteria for study entry often poorly specified. Amongst the studies conducted none have investigated the effects of selective dopaminergic, or noradrenergic agents on tests of working memory, defined in animal research as highly sensitive to prefrontal cortical DA D1 receptor stimulation. The only study conducted to date that attempted to separate dopaminergic and noradrenergic effects on cognitive function used a within-subjects randomised design to compare the effects of an acute dose of methylphenidate, levodopa and desipramine (noradrenaline reuptake inhibitor) on attention and inhibition in 16 boys with ADHD. Methylphenidate improved performance accuracy and reduced reaction times on a go- no go task, whereas levodopa and desipramine had no effect. In contrast, performance on a stop-signal reaction time task was only improved after desipramine. Thus, the authors concluded that while no ameliorating effects of levodopa were noted, desipramine did not mimic the effects of methylphenidate and therefore neither a 'pure' dopaminergic nor noradrenergic explanation is sufficient in understanding the effects of methylphenidate on inhibitory function [125].

The availability of effective pharmacotherapeutics for ADHD in the form of psychomotor stimulant drugs, may explain the rather restricted range of studies examining the effectiveness of selective DA agonists on cognition, in particular working memory in this disorder. A similarly narrow literature is available in patients who have suffered from Traumatic Brain Injury (TBI) or Cerebrovascular Accidents (CVAs). This is surprising considering that working memory and associated deficits are considered a core component of the cognitive deficits associated with TBI [126], with more recent evidence of spatial working memory deficits in patients with parietal neglect following infarction [127-129]. Indeed, there is considerable evidence for monoaminergic dysfunction following TBI, with circulating levels of DA and noradrenaline as possible markers of injury severity and functional recovery [130].

In a small study levodopa (combined with carbidopa) was given to 12 patients following TBI without a placebo control. Outcome measures were based on clinical observation, rather than more objective neuropsychological assessment, but suggested improvements in memory, attention and impulse control as well as cooperation and insight [131]. The time between injury and treatment ranged from 3-52 months in this study, and the observed improvements were dependent upon this interval. Cognitive improvements dependent on the post-injury period were also found in another uncontrolled study using multiple baseline assessments (A-A-B-A design in which $\mathrm{A}=$ non-drug and $\mathrm{B}=\mathrm{drug}$ ) and methylphenidate with 11 patients [132]. Significant improvements in attention were demonstrated for those tested 4-71 days postinjury. In a placebo-controlled study using $2.5 \mathrm{mg}$ bromocriptine, McDowell and colleagues [133] demonstrated improved performance in tasks of executive function (including the Stroop test, verbal fluency and a dual-task paradigm), but not spatial working memory in a group of patients with TBI. Unfortunately, the authors did not report if these improvements were related to the length of post-injury period, which ranged from 27 days to 25 years. Another limitation of their study is that they only examined the effect of a single dose. Therefore, the precise role of post-injury time in dopaminergic enhancement of cognitive recovery is unknown, and requires further exploration as one potentially important predictor of treatment response.

In a more recent study (only published as an abstract) [134], bromocriptine has been shown to have differential effects in healthy controls and patients studied, shortly after mild TBI, on verbal working memory performance and associated changes in brain activation measured with functional magnetic resonance imaging (fMRI). Following bromocriptine, the healthy controls showed improved working memory performance and greater anterior frontal brain activation, whereas the patients showed a decline in performance and greater posterior frontal and parietal activation, suggesting altered mechanisms of action of a DA D2 receptor agonist, at a systems-level, in the patients.

In addition to potential enhancements of working memory and attentional performance, DA agonists may also be beneficial in improving motivational function, assist in re- 
covery from aphasia and have neurotrophic/neuroprotective effects. Powell and colleagues [135] describe a study in which bromocriptine was administered to 11 TBI patients. Following multiple baseline assessments, the authors reported improved motivational and cognitive functions in the absence of mood changes. In 8 of the 11 patients these improvements remained after bromocriptine withdrawal. Since all patients in this study received bromocriptine it is not known if the effects are greater than the effects of placebo, or no treatment. Passler and colleagues [136] also used bromocriptine $(2.5 \mathrm{mg}$, given as $2 \times 1.25 \mathrm{mg})$ in an uncontrolled study with 5 patients with TBI who fulfilled the criteria of vegetative status (TBI-VS). The authors note that these patients recovered faster than a comparable group of cases described in the literature. The outcome measures were the Disability Rating Scale and the Coma Recovery Scale. Notwithstanding the difficulties in conducting studies in such patient groups, from a methodological point of view this investigation does not fulfil the basic characteristics of a scientific study. Therefore, we cannot be confident in the conclusions about bromocriptine. Furthermore, there is no unanimity about the mechanism of action that could explain accelerated recovery. The described improvements in patients following TBI could be due to the specific agonist action of bromocriptine at DA D2 receptors. One mechanism mediating recovery could be direct stimulation of brain regions, modulating cognitive deficits associated with injury. However, as this review has demonstrated (e.g. Table 1) the evidence for this is currently lacking, and limited studies have been conducted in patients. Alternatively, this form of dopaminergic stimulation could lead to accelerated recovery after TBI or TBI-VS by neurogenesis (new formation of neurons and/or their outgrowth) of dopaminergic- and/or other neurons [136].

There have been some reports examining the potential for dopaminergics in the treatment of aphasia. Aphasia (currently used interchangeably with dysphasia) describes linguistic difficulties associated with a brain lesion, commonly following a CVA. The cortical localisation of brain damage resulting in aphasia is varied, with much debate about the precise role of specific regions [137, 138]. Published studies with the dopamine agonist bromocriptine have generally been negative [139-142] with some studies showing positive outcomes for amphetamine [143, 144]. However, in a systematic review for the Cochrane database [145], which only included randomised controlled trials, no positive effects of amphetamine or bromocriptine on the treatment of aphasia after stroke were found. Nevertheless, there is one study that was aimed directly at investigating the interaction of pharmacotherapy and cognitive rehabilitation [144]. Although, the study used amphetamine, and therefore the critical mechanism of action could be dopaminergic, noradrenergic, or both, it deserves mention because of its methodology. Twenty-one patients with aphasia following stroke were given amphetamine (10mg), or placebo, in a double-blind study, for 5 weeks, starting 16 to 45 days after the infarct. During the treatment period there were 10 1-hour sessions of speech and language exercises each of which commenced 10 minutes after the administration of medication. The outcome measure of language function was the Porch Index of Communicative Ability, which was scored before treatment, 1 week after treatment and 6 months after treatment. The analysis conducted corrected for baseline differences in severity and age, but not duration since infarct. One week after treatment both groups had improved, although the amphetamine group improved $54 \%$ more than the placebo group. This reduced to $47 \%$ six months after treatment, but this difference was no longer statistically significant. Regrettably, the group sizes in this otherwise well-designed and interesting study were rather small (partly due to inclusion criterion of one CVA). The authors emphasised the importance of the hypothesis that pharmacotherapy is only useful when it is simultaneously combined with speech- and language therapy, as its therapeutic effect (i.e. plasticity) can be maximised under these conditions [144].

One of the main concerns in studying the effects of DA agonists, or psychomotor stimulants in recovery from TBI, or CVA in particular, is the significant risk of cardiovascular dysregulation. While not all of the aforementioned studies detailed the cardiovascular effects of the treatments used, when reported, no changes were observed [132, 144]. Importantly, a recent study in 40 healthy male volunteers showed that positive effects of acute amphetamine $(0.25 \mathrm{mg} /$ $\mathrm{kg}$ ) on novel word learning were independent of druginduced increases in heart-rate, or blood-pressure [146]. Moreover, similar improvements were reported by the same group for levodopa (100mg for 5 days), which has a lower risk of cardiovascular dysregulation [147]. These studies have implications for the relatively safe reacquisition of sensorimotor and cognitive skills following brain injury.

In summary, the studies in clincal populations (illustrated here with schizophrenia, ADHD, TBI and CVA) suggest that dopaminergic agonists may be beneficial in the amelioration of some cognitive symptoms, although very few studies fulfil elementary criteria of evidence-based medicine. This means that in most cases an insufficient number of patients were included, a control condition (placebo) was lacking or double-blind administration was lacking. Another important issue is selection criteria. While justified in some cases, strict criteria can easily lead to difficulties in understanding how representative any findings are for the wider clinical population.

\section{CONCLUSIONS}

The weight of the evidence presented from research in experimental animals, human volunteers and patients suggests that increased DA stimulation may be beneficial for cognitive functions such as spatial working memory. While the animal research has placed a spotlight on DA D1 receptor stimulation on the apical dendrites of prefrontal pyramidal neurons, a role for DA D2 receptors, possibly in the striatum [148] as well as prefrontal cortical regions [54] cannot be discounted. However, there is a considerable degree of inconsistency in the evidence, particularly for humans (for example, Table 1). Stimulus properties (e.g. spatial vs. nonspatial stimuli), response style (e.g. recall vs. recognition), baseline performance level, genetic polymorphisms, task difficulty, dose of drug and acute versus chronic administration are prominent parameters that may prove to be important predictors of the cognitive effects of DA agonists. Systematic studies of these factors are yet to be conducted, but 
are currently limited by safety concerns for dose ranges that can be safely administered to volunteers, together with the limited array of compounds that are available for use in humans. Alternative strategies, such as pharmacological 'subtraction' [40], or selective 'blocking' [149] designs may be employed to help delineate the effects of non-selective compounds on specific receptor systems. Such methods are, however, non-ideal due to difficulties in matching drug occupancy levels and potencies at receptor sites, as well introducing possible drug interaction effects.

In the published literature to date there has been a particular focus on spatial working memory processes and certain attentional processes, although findings from more recent studies have suggested a broader role for DA in influencing trial-and-error learning $[48,56]$, emotional memory [150, 151], emotional facial recognition [152], attentional switching [153, 154] and action monitoring [155]. The relative importance of DA receptor subtypes in these broader functions has also received less attention than for spatial working memory tasks and should be a focus for future studies. In addition there is predicted regional variation in these effects, with, for example, emotional memory modulation probably mediated in part by DA D2 receptors in the amygdala [150].

Therefore, talking of 'DA function' per se may not be a useful strategy when considering the differential distribution of receptors across the brain and that selective ligands do not exist for each of the known subtypes of receptors $\left(D_{1}-D_{5}\right)$. For example, synaptic DA $D_{1}$ receptors in the PFC are known to be important for spatial working memory tasks in the monkey, whereas the distribution of $\mathrm{DA} \mathrm{D}_{5}$ receptors (which have affinity for DA a magnitude higher than DA $D_{1}$ receptors [156]) is distinct, possibly to facilitate diffuse dopaminoception [157]. Similarly the effects of altered DA neurotransmission in the striatum (including the nucleus accumbens) may be mediated via $\mathrm{D}_{1}, \mathrm{D}_{2}$, or $\mathrm{D}_{3}$ receptor subtypes, with a particular challenge being the separation of effects at $D_{2}$ and $D_{3}$ receptor subtypes. While differential effects at these latter receptor subtypes is recognised as potentially important in understanding antipsychotic drug efficacies [158], the relative importance on cognitive function has received considerably less attention. Thus, a particular challenge for the future is a more refined understanding of the precise roles of DA receptor subtypes in mediating cognitive functions, with potential not only for cognitive enhancement, but also the prevention of context-specific cognitive impairment [159].

Such studies could benefit clinical investigations of dopamine agonists in the treatment of neurocognitive disorders. Although inconclusive, these have strongly suggested that DA neurotransmission is an important factor in improving cognitive impairments associated with certain disorders such as schizophrenia, attention-deficit hyperactivity disorder, Parkinson's disease and following head injury or a CVA. Moreover, studies of novel word learning suggest that DA agonists may accelerate recovery of language function, however carefully controlled studies in patients are necessary to confirm the potential utility of such interventions in clinical practice.

\section{REFERENCES}

References 160-162 are related articles recently published in Current Pharmaceutical Design.

[1] Algeri S, Carolei A, Ferretti P, Gallone C, Palladini G, Venturini G. Effects of dopaminergic agents on monoamine levels and motor behaviour in planaria. Comp Biochem Physiol C 1983; 74: 27-9.

[2] Doshi PS, Edwards DJ. Effects of L-dopa on dopamine and norepinephrine concentrations in rat brain assessed by gas chromatography. J Chromatogr 1981; 210: 505-11.

[3] Dolphin A, Jenner P, Marsden CD. Noradrenaline synthesis from L-DOPA in rodents and its relationship to motor activity. Pharmacol Biochem Behav 1976; 5: 431-9.

[4] Arnsten AF. Catecholamine regulation of the prefrontal cortex. J Psychopharmacol 1997; 11: 151-62.

[5] Arnsten AFT, Robbins TW. In: Stuss DT, Knight RT, Eds., Neurochemical modulation of prefrontal cortical function in humans and animals. Principles of frontal lobe function. USA: Oxford University Press 2002; 51-84.

[6] Grimm J, Mueller A, Hefti F, Rosenthal A. Molecular basis for catecholaminergic neuron diversity. Proc Natl Acad Sci USA 2004; 101: 13891-13896.

[7] Lewis DA, Campbell MJ, Foote GL, Goldstein M, Morrison JH. The distribution of tyrosine hydroxylase-immunoreactive fibers in primate neocortex is widespread, but regionally specific. J Neurosci 1987; 7: 279-290

[8] Williams SM, Goldman-Rakic PS. Characterization of the dopaminergic innervation of the primate frontal cortex using a dopamine-specific antibody. Cerebral Cortex 1993; 3: 199-222.

[9] Hall H, Sedvall G, Magnusson O, Kopp J, Halldin C, Farde L. Distribution of D1- and D2-dopamine receptors, and dopamine and its metabolites in the human brain. Neuropsychopharmacology 1994; 11: 245-56.

[10] Camps M, Cortes R, Gueye B, Probst A, Palacios JM. Dopamine receptors in human brain: autoradiographic distribution of D2 sites. Neuroscience 1989; 28: 275-90.

[11] Cortes R, Gueye B, Pazos A, Probst A, Palacios JM. Dopamine receptors in human brain: autoradiographic distribution of D1 sites. Neuroscience 1989; 28: 263-73.

[12] Laruelle M. Imaging dopamine transmission in schizophrenia. A review and meta- analysis. Q J Nucl Med 1998; 42: 211-21.

[13] Missale C, Nash SR, Robinson SW, Jaber M, Caron MG. Dopamine receptors: from structure to function. Physiological Review 1998; 78: 189-225.

[14] Neve KA, Neve RL. The dopamine receptors. Totowa, N.J.: Humana. 1997

[15] Spano PF, Giovoni S, Trabucchi M. Studies on the pharmacological properties of dopamine receptors in various areas of the central nervous system. Adv Biochem Psychopharmacol 1978; 19: 155165 .

[16] Kebabian JW, Calne DB. Multiple receptors for dopamine. Nature 1979; 277: 93-99.

[17] Andersen PH, Gingrich JA, Bates MD, Dearry A, Falardeau P, Senogles SE, et al. Dopamine receptor subtypes: beyond the $\mathrm{D}_{1} / \mathrm{D}_{2}$ classification. Trends Pharmacol Sci 1990; 11: 231-236.

[18] Buyukuysal RL, Mogol E. Synthesis and release of dopamine in rat striatal slices: requirement for exogenous tyrosine in the medium. Neurochem Res 2000; 25: 533-40.

[19] Gasparini M, Fabrizio E, Bonifati V, Meco G. Cognitive improvement during Tolcapone treatment in Parkinson's disease. J Neural Transm 1997; 104: 887-94.

[20] Passingham R. Delayed matching after selective prefrontal lesions in monkeys (Macaca mulatta). Brain Res 1975; 92: 89-102.

[21] Passingham RE. Memory of monkeys (Macaca mulatta) with lesions in prefrontal cortex. Behav Neurosci 1985; 99: 3-21.

[22] Goldman-Rakic PS. In: Plum F, Ed., Circuitry of primate prefrontal cortex and regulation of behaviour by representational memory. Handbook of Physiology; Nervous System, vol. 5 Higher Functions of the Brain (part 1). Bethesda, MD: American Physiological Society $1987 ; 373-417$. 
[23] Butters N, Pandya D, Sanders K, Dye P. Behavoral deficits in monkeys after selective lesions within the middle third of sulcus principalis. J Comp Physiol Psychol 1971; 76: 8-14.

[24] Bauer RH, Fuster JM. Delayed-matching and delayed-response deficit from cooling dorsolateral prefrontal cortex in monkeys. J Comp Physiol Psychol 1976; 90: 293-302.

[25] Stamm JS, Weber-Levine ML. Delayed alternation impairments following selective prefrontal cortical ablations in monkeys. Exp Neurol 1971; 33: 263-78.

[26] Phillips AG, Ahn S, Floresco SB. Magnitude of dopamine release in medial prefrontal cortex predicts accuracy of memory on a delayed response task. J Neurosci 2004; 24: 547-53.

[27] Brozoski TJ, Brown RM, Rosvold HE, Goldman PS. Cognitive deficit caused by regional depletion of dopamine in prefrontal cortex of rhesus monkey. Science 1979; 205: 929-32.

[28] Roberts AC, De Salvia MA, Wilkinson LS, Collins P, Muir JL, Everitt BJ, et al. 6-Hydroxydopamine lesions of the prefrontal cortex in monkeys enhance performance on an analog of the Wisconsin Card Sort Test: possible interactions with subcortical dopamine. J Neurosci 1994; 14: 2531-44.

[29] Sawaguchi T, Goldman-Rakic PS. D1 dopamine receptors in prefrontal cortex: involvement in working memory. Science 1991; 251: $947-50$.

[30] Williams GV, Goldman-Rakic PS. Blockade of dopamine D1 receptors enhances memory fields of prefrontal neurons in primate cerebral cortex. Nature 1995; 376: 572-575.

[31] Sawaguchi T, Goldman-Rakic PS. The role of D1-dopamine receptor in working memory: local injections of dopamine antagonists into the prefrontal cortex of rhesus monkeys performing an oculomotor delayed-response task. J Neurophysiol 1994; 71: 51528.

[32] Cai JX, Arnsten AF. Dose-dependent effects of the dopamine D1 receptor agonists A77636 or SKF81297 on spatial working memory in aged monkeys. J Pharmacol Exp Ther 1997; 283: 183-9.

[33] Arnsten AF, Cai JX, Murphy BL, Goldman-Rakic PS. Dopamine D1 receptor mechanisms in the cognitive performance of young adult and aged monkeys. Psychopharmacology (Berl) 1994; 116: 143-51.

[34] Arnsten AF, Goldman-Rakic PS. Noise stress impairs prefrontal cortical cognitive function in monkeys: evidence for a hyperdopaminergic mechanism. Arch Gen Psychiatry 1998; 55: 362-8.

[35] Zahrt J, Taylor JR, Mathew RG, Arnsten AF. Supranormal stimulation of D1 dopamine receptors in the rodent prefrontal cortex impairs spatial working memory performance. J Neurosci 1997; 17: 8528-35.

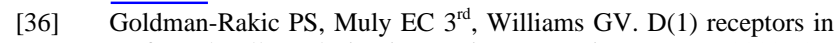
prefrontal cells and circuits. Brain Res Brain Res Rev 2000; 31 : 295-301.

[37] Castner SA, Goldman-Rakic PS. Enhancement of working memory in aged monkeys by a sensitizing regimen of dopamine $\mathrm{d} 1$ receptor stimulation. J Neurosci 2004; 24: 1446-50.

[38] Castner SA, Williams GV, Goldman-Rakic PS. Reversal of antipsychotic-induced working memory deficits by short-term dopamine D1 receptor stimulation. Science 2000; 287: 2020-2.

[39] Rascol O, Blin O, Thalamas C, Descombes S, Soubrouillard C, Azulay $\mathrm{P}$, et al. ABT-431, a D1 receptor agonist prodrug, has efficacy in Parkinson's disease. Ann Neurol 1999; 45: 736-41.

[40] Müller U, von Cramon DY, Pollmann S. D1- versus D2-receptor modulation of visuospatial working memory in humans. J Neurosci 1998; 18: 2720-8.

[41] Sahakian BJ. In: Iversen LL, Iversen SD, Snyder SH, Eds., Cholinergic drugs and human cognitive performance. Handbook of Psychopharmacology. New York: Plenum Press 1988; 393-424.

[42] Mehta MA, Sahakian BJ, Robbins TW. In: Solanto MV, Arnsten AFT, Castellanos FX, Eds., Comparative psychopharmacology of methylphenidate and related drugs in human volunteers, patients with $\mathrm{AD} / \mathrm{HD}$ and experimental animals. Stimulant Drugs and AD/HD: Basic and Clinical Neuroscience. New York: Oxford University Press 2001; 303-331.

[43] Arnsten AF, Cai JX, Steere JC, Goldman-Rakic PS. Dopamine D2 receptor mechanisms contribute to age-related cognitive decline: the effects of quinpirole on memory and motor performance in monkeys. J Neurosci 1995; 15: 3429-39.
[44] Collins P, Wilkinson LS, Everitt BJ, Robbins TW, Roberts AC. The effect of dopamine depletion from the caudate nucleus of the common marmoset (Callithrix jacchus) on tests of prefrontal cognitive function. Behav Neurosci 2000; 114: 3-17.

[45] Suri RE, Schultz W. A neural network model with dopamine-like reinforcement signal that learns a spatial delayed response task. Neuroscience 1999; 91: 871-90.

[46] Schultz W, Apicella P, Ljungberg T. Responses of monkey dopamine neurons to reward and conditioned stimuli during successive steps of learning a delayed response task. J Neurosci 1993; 13: 90013.

[47] Schultz W. Neural coding of basic reward terms of animal learning theory, game theory, microeconomics and behavioural ecology. Curr Opin Neurobiol 2004; 14: 139-47.

[48] Schultz W. The phasic reward signal of primate dopamine neurons. Adv Pharmacol 1998; 42: 686-90.

[49] Ungless MA. Dopamine: the salient issue. Trends Neurosci 2004; 27: 702-706.

[50] Redgrave P, Prescott TJ, Gurney K. Is the short-latency dopamine response too short to signal reward error? Trends Neurosci 1999; 22: 146-51.

[51] Granon S, Passetti F, Thomas KL, Dalley JW, Everitt BJ, Robbins TW. Enhanced and impaired attentional performance after infusion of D1 dopaminergic receptor agents into rat prefrontal cortex. J Neurosci 2000; 20: 1208-15.

[52] Kimberg DY, D'Esposito M, Farah MJ. Effects of bromocriptine on human subjects depends on working memory capacity. Neuroreport 1997; 8: 3581-3585.

[53] Mehta MA, Owen AM, Sahakian BJ, Mavaddat N, Pickard JD, Robbins TW. Methylphenidate enhances working memory by modulating discrete frontal and parietal lobe regions in the human brain. J Neurosci (Online) 2000; 20: RC65.

[54] Wang M, Vijayraghavan S, Goldman-Rakic PS. Selective D2 receptor actions on the functional circuitry of working memory. Science 2004; 303: 853-6.

[55] Crofts HS, Dalley JW, Collins P, Van Denderen JC, Everitt BJ, Robbins TW, et al. Differential effects of 6-OHDA lesions of the frontal cortex and caudate nucleus on the ability to acquire an attentional set. Cereb Cortex 2001; 11: 1015-26.

[56] Young AM, Ahier RG, Upton RL, Joseph MH, Gray JA. Increased extracellular dopamine in the nucleus accumbens of the rat during associative learning of neutral stimuli. Neuroscience 1998; 83: 1175-83.

[57] Schultz W, Dayan P, Montague PR. A neural substrate of prediction and reward. Science 1997; 275: 1593-9.

[58] Lueck CJ, Tanyeri S, Crawford TJ, Henderson L, Kennard C. Antisaccades and remembered saccades in Parkinson's disease. J Neurol Neurosurg Psychiatry 1990; 53: 284-8.

[59] Postle BR, Jonides J, Smith EE, Corkin S, Growdon JH. Spatial, but not object, delayed response is impaired in early Parkinson's disease. Neuropsychology 1997; 11: 171-9.

[60] Fournet N, Moreaud O, Roulin JL, Naegele B, Pellat J. Working memory functioning in medicated Parkinson's disease patients and the effect of withdrawal of dopaminergic medication. Neuropsychology 2000; 14: 247-53.

[61] Fern-Pollak L, Whone AL, Brooks DJ, Mehta MA. Cognitive and motor effects of dopaminergic medication withdrawal in Parkinson's disease. Neuropsychologia 2004; 42: 1917-1926.

[62] Lewis SJG, Slabosz A, Robbins TW, Barker RA, Owen AM. Dopaminergic basis for deficits in working memory but not attentional set-shifting in Parkinson's disease. Neuropsychologia 2005; 43: 823-832.

[63] Luciana M, Depue RA, Arbisi P, Leon A. Facilitation of working memory in humans by a $\mathrm{D}_{2}$ dopamine receptor agonist. J Cogn Neurosci 1992; 4: 58-67.

[64] Luciana M, Collins PF. Dopaminergic modulation of working memory for spatial but not object cues in normal volunteers. J Cogn Neurosci 1997; 9: 330-347.

[65] Bartholomeusz CF, Box G, Van Rooy C, Nathan PJ. The modulatory effects of dopamine D1 and D2 receptor function on object working memory in humans. J Psychopharmacol 2003; 17: 9-15. 
[66] Luciana M, Collins PF, Depue RA. Opposing roles for dopamine and serotonin in the modulation of human spatial working memory functions. Cereb Cortex 1998; 8: 218-26.

[67] Roesch-Ely D, Scheffel H, Weiland S, Schwaninger M, Hundemer $\mathrm{H}-\mathrm{P}$, Kolter T, et al. Differential dopaminergic modulation of executive control in healthy subjects. Psychopharmacology 2005; 178: 420-430.

[68] Mehta MA, Swainson R, Ogilvie AD, Sahakian J, Robbins TW. Improved short-term spatial memory but impaired reversal learning following the dopamine D2 agonist bromocriptine in human volunteers. Psychopharmacology (Berl) 2001; 159: 10-20.

[69] Ellis KA, Nathan PJ. The pharmacology of human working memory. Int J Neuropsychopharm 2001; 4: 299-313.

[70] Kapur S, Roy P, Daskalakis J, Remington G, Zipursky R. Increased dopamine $d(2)$ receptor occupancy and elevated prolactin level associated with addition of haloperidol to clozapine. Am J Psychiatry 2001; 158: 311-4.

[71] Kapur S, Zipursky R, Jones C, Remington G, Houle S. Relationship between dopamine $\mathrm{D}(2)$ occupancy, clinical response, and side effects: a double-blind PET study of first-episode schizophrenia. Am J Psychiatry 2000; 157: 514-20.

[72] Kimberg DY, D'Esposito M. Cognitive effects of the dopamine receptor agonist pergolide. Neuropsychologia 2003; 41: 1020-7.

[73] Kimberg DY, Aguirre GK, Lease J, D'Esposito M. Cortical effects of bromocriptine, a D-2 dopamine receptor agonist, in human subjects, revealed by fMRI. Hum Brain Mapp 2001; 12: 246-57.

[74] Mehta AE, Tolis G. Pharmacology of bromocriptine in health and disease. Drugs 1979; 17: 313-25.

[75] Pizzolato G, Soncrant TT, Rapoport SI. Time-course and regional distribution of the metabolic effects of bromocriptine in the rat brain. Brain Res 1985; 341: 303-312.

[76] Brown VJ, Robbins TW. Simple and choice reaction time performance following unilateral striatal dopamine depletion in the rat. Impaired motor readiness but preserved response preparation. Brain 1991; 114: 513-25.

[77] Clark CR, Geffen GM, Geffen LB. Catecholamines and attention II: pharmacological studies in normal volunteers. Neurosci Biobehav Rev 1987; 11: 353-364.

[78] Reeves S, Howard R, Bench C. Ageing and the nigrostriatal dopaminergic system. Int J Geriatr Psychiatry 2002; 17: 359-370.

[79] Newman RP, Weingarter H, Smallberg SA, Calne DB. Effortful and automatic memory: effects of dopamine. Neurology 1984; 34 : 805-807.

[80] Hastak SM. Treatment of memory impairment, vertigo and tinnitus in the elderly with piribedil in an Indian general practice setting. $\mathrm{J}$ Indian Med Assoc 2003; 101: 500-501.

[81] Schuck S, Bentue-Ferrer D, Kleinermans D, Reymann JM, Polard $\mathrm{E}$, Gandon JM, et al. Psychomotor and cognitive effects of piribedil, a dopamine agonist, in young healthy volunteers. Fundam Clin Pharmacol 2002; 16: 57-65.

[82] Kirchheiner J, Nickchen K, Bauer M, Wong ML, Licinio J, Roots I, et al. Pharmacogenetics of antidepressants and antipsychotics: the contribution of allelic variations to the phenotype of drug response. Mol Psychiatry 2004; 9: 442-73.

[83] Lachman HM, Papolos DF, Saito T, Yu YM, Szumlanski CL, Weinshilboum RM. Human catechol-O-methyltransferase pharmacogenetics: description of a functional polymorphism and its potential application to neuropsychiatric disorders. Pharmacogenetics 1996; 6: 243-250.

[84] Jonsson EG, Nothen MM, Grunhage F, Farde L, Nakashima Y, Propping $\mathrm{P}$, et al. Polymorphisms in the dopamine D2 receptor gene and their relationships to striatal dopamine receptor density of healthy volunteers. Mol Psychiatry 1999; 4: 290-6.

[85] Egan MF, Goldberg TE, Kolachana BS, Callicott JH, Mazzanti CM, Straub RE, et al. Effect of COMT Val108/158 Met genotype on frontal lobe function and risk for schizophrenia. Proc Natl Acad Sci USA 2001; 98: 6917-22.

[86] Bilder RM, Volavka J, Lachman HM, Grace AA. The catechol- $O$ methyltransferase polymorphism: relations to the tonic-phasic dopamine hypothesis and neuropsychiatric phenotypes. Neuropsychopharmacology 2004; 29: 1943-1961.

[87] Foltynie T, Goldberg TE, Lewis SGJ, Blackwell AD, Kolachana BS, Weinberger DR, et al. Planning ability in Parkinson's disease is influenced by the COMT Val ${ }^{158}$ Met polymorphism. Mov Disord 2004; 19: 885-891.

[88] Weickert TW, Goldberg TE, Mishara A, Apud JA, Kolachana BS, Egan MF, et al. Catechol-O-methyltransferase Val ${ }^{108 / 158}$ Met genotype predicts working memory response to antipsychotic medications. Biological Psychiatry 2004; 56: 677-682.

[89] Kuczenski R, Segal DS. Effects of methylphenidate on extracellular dopamine, serotonin, and norepinephrine: comparison with amphetamine. J Neurochem 1997; 68: 2032-7.

[90] Koelega HS. Stimulant drugs and vigilance performance: a review. Psychopharmacology (Berl) 1993; 111: 1-16.

[91] Camp-Bruno JA, Herting RL. Cognitive effects of milacemide and methylphenidate in healthy young adults. Psychopharmacology 1994; 115: 46-52.

[92] Weiss B, Laties VG. Enhancement of human performance by caffeine and the amphetamines. Pharmacol Rev 1962; 14: 1-36.

[93] Elliott R, Sahakian BJ, Matthews K, Bannerjea A, Rimmer J, Robbins TW. Effects of methylphenidate on spatial working memory and planning in healthy young adults. Psychopharmacology (Berl) 1997; 131: 196-206.

[94] Coull JT, Middleton HC, Robbins TW, Sahakian BJ. Contrasting effects of clonidine and diazepam on tests of working memory and planning. Psychopharmacology (Berl) 1995; 120: 311-21.

[95] Mehta MA, Sahakian BJ, McKenna PJ, Robbins TW. Systemic sulpiride in young adult volunteers simulates the profile of cognitive deficits in Parkinson's disease. Psychopharmacology (Berl) 1999; 146: 162-74.

[96] Rogers RD, Blackshaw AJ, Middleton HC, Matthews K, Hawtin K, Crowley $\mathrm{C}$, et al. Tryptophan depletion impairs stimulus-reward learning while methylphenidate disrupts attentional control in healthy young adults: implications for the monoaminergic basis of impulsive behaviour. Psychopharmacology (Berl) 1999; 146: 48291.

[97] Grant DA, Berg EA. A behavioural analysis of degree of reinforcement and ease of shifting to new responses in a Weigl-type card-sorting problem. J Exp Psychol 1948; 38: 404-411.

[98] Mehta MA, Goodyer IM, Sahakian BJ. Methylphenidate improves working memory and set-shifting in AD/HD: relationships to baseline memory capacity. J Child Psychol Psychiatry 2004; 45: 293305.

[99] Turner DC, Robbins TW, Clark L, Aron AR, Dowson J, Sahakian BJ. Relative lack of cognitive effects of methylphenidate in elderly male volunteers. Psychopharmacology (Berl) 2003; 168: 455-64.

[100] Dujardin K, Laurent B. Dysfunction of the human memory systems: role of the dopaminergic transmission. Curr Opin Neurol 2003; 16: S11-16.

[101] Kulisevsky J. Role of dopamine in learning and memory: implications for the treatment of cognitive dysfunction in patients with Parkinson's disease. Drugs Aging 2000; 16: 365-79.

[102] Nieoullon A. Dopamine and the regulation of cognition and attention. Prog Neurobiol 2002; 67: 53-83.

[103] Owen AM. Cognitive dysfunction in Parkinson's disease: the role of frontostriatal circuitry. Neuroscientist 2004; 10: 525-537.

[104] Goldman-Rakic PS, Castner SA, Svensson TH, Siever LJ, Williams GV. Targeting the dopamine D1 receptor in schizophrenia: insights for cognitive dysfunction. Psychopharmacology (Berl) 2004; 174 : 3-16.

[105] Okubo Y, Suhara T, Suzuki K, Kobayashi K, Inoue O, Terasaki O, et al. Decreased prefrontal dopamine D1 receptors in schizophrenia revealed by PET. Nature 1997; 385: 634-6.

[106] Karlsson P, Farde L, Halldin C, Sedvall G. PET study of D(1) dopamine receptor binding in neuroleptic-naive patients with schizophrenia. Am J Psychiatry 2002; 159: 761-7.

[107] Abi-Dargham A, Mawlawi O, Lombardo I, Gil R, Martinez D, Huang Y, et al. Prefrontal dopamine D1 receptors and working memory in schizophrenia. J Neurosci 2002; 22: 3708-19.

[108] Gunn RN, Lammertsma AA, Grasby PM. Quantitative analysis of [carbonyl-(11)C]WAY-100635 PET studies. Nucl Med Biol 2000; 27: 477-482.

[109] Abi-Dargham A. Do we still believe in the dopamine hypothesis? New data bring new evidence. Int J Neuropsychopharmacol 2004; 7(Suppl 1): S1-5. 
[110] Laruelle M, Abi-Dargham A, van Dyck CH, Gil R, D'Souza CD, Erdos J, et al. Single photon emission computerized tomography imaging of amphetamine- induced dopamine release in drug-free schizophrenic subjects. Proc Natl Acad Sci USA 1996; 93: 923540.

[111] Kempton S, Vance A, Maruff P, Luk E, Costin J, Pantelis C. Executive function and attention deficit hyperactivity disorder: stimulant medication and better executive function performance in children. Psychol Med 1999; 29: 527-38.

[112] Konrad K, Gunther T, Hanisch C, Herpertz-Dahlmann B. Differential effects of methylphenidate on attentional functions in children with attention-deficit/hyperactivity disorder. J Am Acad Child Adolesc Psychiatry 2004; 43: 191-8.

[113] Leonard BE, McCartan D, White J, King DJ. Methylphenidate: a review of its neuropharmacological, neuropsychological and adverse clinical effects. Hum Psychopharmacol 2004; 19: 151-80.

[114] Pennington BF, Ozonoff S. Executive functions and developmental psychopathology. J Child Psychol Psychiatry 1996; 37: 51-87.

[115] Levy F, Swanson JM. Timing, space and ADHD: the dopamine theory revisited. Aust N Z J Psychiatry 2001; 35: 504-11.

[116] Solanto MV. Neuropsychopharmacological mechanisms of stimulant drug action in attention-deficit hyperactivity disorder: a review and integration. Behav Brain Res 1998; 94: 127-52.

[117] Sergeant JA, Geurts H, Huijbregts S, Scheres A, Oosterlaan J. The top and the bottom of ADHD: a neuropsychological perspective. Neurosci Biobehav Rev 2003; 27: 583-92.

[118] Sergeant JA, Geurts H, Oosterlaan J. How specific is a deficit of executive functioning for attention-deficit/hyperactivity disorder? Behav Brain Res 2002; 130: 3-28.

[119] Denney CB, Rapport MD. In: Solanto MV, Arnsten AFT, Castellanos FX, Eds., The Cognitive Pharmacology of Stimulants in Children with ADHD. Stimulant Drugs and ADHD: Basic and Clinical Neuroscience. New York: Oxford University Press 2001; 283-302.

[120] Reimherr FW, Wood DR, Wender PH. An open clinical trial of Ldopa and carbidopa in adults with minimal brain dysfunction. Am J Psychiatry 1980; 137: 73-5.

[121] Wood D, Reimherr F, Wender PH. Effects of levodopa on attention deficit disorder, residual type. Psychiatry Res 1982; 6: 13-20.

[122] Langer DH, Rapoport JL, Brown GL, Ebert MH, Bunney WE, Jr. Behavioral effects of carbidopa/levodopa in hyperactive boys. J Am Acad Child Psychiatry 1982; 21: 10-8.

[123] Rapoport JL, Buchsbaum MS, Weingartner H, Zahn TP, Ludlow C, Mikkelsen EJ. Dextroamphetamine. Its cognitive and behavioral effects in normal and hyperactive boys and normal men. Arch Gen Psychiatry 1980; 37: 933-43.

[124] Walters AS, Mandelbaum DE, Lewin DS, Kugler S, England SJ, Miller M. Dopaminergic therapy in children with restless legs/periodic limb movements in sleep and ADHD. Dopaminergic Therapy Study Group. Pediatr Neurol 2000; 22: 182-6.

[125] Overtoom CC, Verbaten MN, Kemner C, Kenemans JL, van Engeland H, Buitelaar JK, et al. Effects of methylphenidate, desipramine, and L-dopa on attention and inhibition in children with Attention Deficit Hyperactivity Disorder. Behav Brain Res 2003; 145: 7-15.

[126] McAllister TW, Flashman LA, Sparling MB, Saykin AJ. Working memory deficits after traumatic brain injury: catecholaminergic mechanisms and prospects for treatment -- a review. Brain Inj 2004; 18: 331-50.

[127] Wojciulik E, Husain M, Clarke K, Driver J. Spatial working memory deficit in unilateral neglect. Neuropsychologia 2001; 39: 390-6.

[128] Wojciulik E, Rorden C, Clarke K, Husain M, Driver J. Group study of an "undercover" test for visuospatial neglect: invisible cancellation can reveal more neglect than standard cancellation. J Neurol Neurosurg Psychiatry 2004; 75: 1356-8.

[129] Pisella L, Berberovic N, Mattingley JB. Impaired working memory for location but not for colour or shape in visual neglect: a comparison of parietal and non-parietal lesions. Cortex 2004; 40: 37990.

[130] McIntosh TK. Neurochemical sequelae of traumatic brain injury: therapeutic implications. Cerebraovasc Brain Metab Rev 1994; 6: 109-162.

[131] Lal S, Merbtiz CP, Grip JC. Modification of function in headinjured patients with Sinemet. Brain Inj 1988; 2: 225-33.
[132] Kaelin DL, Cifu DX, Matthies B. Methylphenidate effect on attention deficit in the acutely brain-injured adult. Arch Phys Med Rehabil 1996; 77: 6-9.

[133] McDowell S, Whyte J, D'Esposito M. Differential effect of a dopaminergic agonist on prefrontal function in traumatic brain injury patients. Brain 1998; 121: 1155-64.

[134] McAllister TW, Flashman LA, Shaw PK, Ferrell RB, Wishart HA, McDonald BC, et al. Differential activation of working memoryassociated frontal cortex using a dopamine agonist after mild traumatic brain injury (MTBI). Journal of Neuropsychiatry and Clinical Neuroscience 2003; 15: 278.

[135] Powell JH, al-Adawi S, Morgan J, Greenwood RJ. Motivational deficits after brain injury: effects of bromocriptine in 11 patients. $\mathrm{J}$ Neurol Neurosurg Psychiatry 1996; 60: 416-21.

[136] Passler MA, Riggs RV. Positive outcomes in traumatic brain injury-vegetative state: patients treated with bromocriptine. Arch Phys Med Rehabil 2001; 82: 311-5.

[137] Blank SC, Scott SK, Murphy K, Warburton E, Wise RJ. Speech production: Wernicke, Broca and beyond. Brain 2002; 125: 182938 .

[138] Dronkers NF, Wilkins DP, Van Valin RD Jr, Redfern BB, Jaeger JJ. Lesion analysis of the brain areas involved in language comprehension. Cognition 2004; 92: 145-77.

[139] Ozeren A, Sarica Y, Mavi H, Demirkiran M. Bromocriptine is ineffective in the treatment of chronic nonfluent aphasia. Acta Neurol Belg 1995; 95: 235-8.

[140] Gupta SR, Mlcoch AG, Scolaro C, Moritz T. Bromocriptine treatment of nonfluent aphasia. Neurology 1995; 45: 2170-3.

[141] Sabe L, Salvarezza F, Garcia Cuerva A, Leiguarda R, Starkstein S. A randomized, double-blind, placebo-controlled study of bromocriptine in nonfluent aphasia. Neurology 1995; 45: 2272-4.

[142] Bragoni M, Altieri M, Di Piero V, Padovani A, Mostardini C, Lenzi GL. Bromocriptine and speech therapy in non-fluent chronic aphasia after stroke. Neurol Sci 2000; 21: 19-22.

[143] Altieri M, Di Piero V, Lenzi GL. Drugs and recovery: a challenge for a few? Stroke 2002; 33: 1170.

[144] Walker-Batson D, Curtis S, Natarajan R, Ford J, Dronkers N, Salmeron E, et al. A double-blind, placebo-controlled study of the use of amphetamine in the treatment of aphasia. Stroke 2001; 32: 2093-8.

[145] Greener J, Enderby P, Whurr R. Pharmacological treatment for aphasia following stroke. Cochrane Database Syst Rev 2001: CD000424.

[146] Breitenstein C, Wailke S, Bushuven S, Kamping S, Zwitserlood P, Ringelstein EB, et al. D-amphetamine boosts language learning independent of its cardiovascular and motor arousing effects. Neuropsychopharmacology 2004; 29: 1704-14.

[147] Knecht S, Breitenstein C, Bushuven S, Wailke S, Kamping S, Floel $A$, et al. Levodopa: faster and better word learning in normal humans. Ann Neurol 2004; 56: 20-6.

[148] Mehta MA, McGowan S, Lawrence AD, Aitken MFR, Montgomery AJ, Grasby PM. Systemic sulpiride modulates striatal blood flow: relationships to spatial working memory and planning. Neuroimage 2003; 20: 1982-1994.

[149] Levy F, Hobbes G. Does haloperidol block methylphenidate? Motivation or attention? Psychopharmacology 1996; 126: 70-74.

[150] Rosenkranz JA, Grace AA. Dopamine-mediated modulation of odour-evoked amygdala potentials during pavlovian conditioning. Nature 2003; 417: 282-287.

[151] Mehta MA, Hinton EC, Montgomery AJ, Bantick RA, Grasby PM. Sulpiride and mnemonic function: effects of a dopamine D2 receptor antagonist on working memory, emotional memory and long-term memory in healthy volunteers. Journal of Psychopharmacology 2004; 19: 29-38.

[152] Lawrence AD, Calder AJ, McGowan SW, Grasby PM. Selective disruption of the recognition of facial expressions of anger. Neuroreport 2002; 13: 881-884.

[153] Cools R, Barker RA, Sahakian BJ, Robbins TW. L-Dopa medication remediates cognitive inflexibility, but increases impulsivity in patients with Parkinson's disease. Neuropsychologia 2003; 41: 1431-41.

[154] Mehta MA, Manes FF, Magnolfi G, Sahakian BJ, Robbins TW. Impaired set-shifting and dissociable effects on tests of spatial 
working memory following the dopamine $\mathrm{D}(2)$ receptor antagonist sulpiride in human volunteers. Psychopharmacology (Berl) 2004; 176: 331-342.

[155] DeBruijn ERA, Hulstijn W, Verkes RJ, Ruigt GSF, Sabbe BGC. Drug-induced stimulation and suppression of action monitoring in healthy volunteers. Psychopharmacology (Berl) 2004; 177: 151160 .

[156] Sunahara RK, Guan HC, O'Dowd BF, Seeman P, Laurier LG, Ng $\mathrm{G}$, et al. Cloning of the gene for a human dopamine $\mathrm{D}_{5}$ receptor with higher affinity for dopamine than $\mathrm{D}_{1}$. Nature 1991; 350: 614619.

[157] Paspalas CD, Goldman-Rakic PS. Microdomains for dopamine volume neurotransmission in primate prefrontal cortex. J Neurosci 2004; 24: 5292-5300.

[158] Yamada S, Takaki T, Yokoo H, Tanaka M. Differential effects of dopamine antagonists on evoked dopamine release from slices of striatum and nucleus accumbens in rats. J Pharm Pharmacol 1995; 47: 259-62.

[159] Arnsten AF, Murphy B, Merchant K. The selective dopamine D4 receptor antagonist, PNU-101387G, prevents stress-induced cognitive deficits in monkeys. Neuropsychopharmacology 2000; 23: 405-10.

[160] de Bartolomeis A, Fiore G, Iasevoli F. Dopamine-glutamate interaction and antipsychotics mechanism of action: implication for new pharmacological strategies in psychosis. Curr Pharm Des 2005; 11(27): 3561-94.

[161] Guilloteau D, Chalon S. PET and SPECT exploration of central monoaminergic transporters for the development of new drugs and treatments in brain disorders. Curr Pharm Des 2005; 11(25): 323745.

[162] Thomas M, Le WD. Minocycline: neuroprotective mechanisms in Parkinson's disease. Curr Pharm Des 2004; 10(6): 679-86. 